\title{
Methionine plus cystine requirements for the maintenance and efficiency of utilization with tambaqui of different body weights
}

\section{Exigência de metionina mais cistina para mantença e eficiência de utilização do tambaqui com diferentes pesos corporais}

\author{
Neliane Galvão Porto ${ }^{1}$ (D) Felipe Barbosa Ribeiro ${ }^{2 *}$ (D) , Jefferson Costa de Siqueira² ${ }^{\text {(D), }}$ \\ Marcos Antonio Delmondes Bomfim² (i), Rafael Silva Marchão ${ }^{3}$ (D), Dayana da Conceição da Costa ${ }^{1}$
}

\author{
'Universidade Federal do Maranhão/UFMA, Chapadinha, MA, Brasil \\ ¿Universidade Federal do Maranhão/UFMA, Centro de Ciências Agrárias e Ambientais, Chapadinha, MA, Brasil \\ 3Universidade Federal do Vale do São Francisco/UNIVASF, Petrolina, PE, Brasil \\ *Corresponding author: felipe.barbosa@ufma.br \\ Received in June 17, 2020 and approved in September 21, 2020
}

\begin{abstract}
Methionine is an essential amino acid, and generally, the first limiting one in the diets of tambaqui, the main native fish produced in continental aquaculture in South America. However, there is a lack of information on their amino acid requirement, especially for maintenance and efficiency of utilization. The present study aimed to determine the requirement of [methionine plus cystine] for the maintenance and efficiency of utilization using tambaqui of different body weights. Two experiments were carried out using 250 tambaqui with weights of 100 and $300 \mathrm{~g}$. They were distributed in a completely randomized design with four treatment groups $(0.264,0.396,0.528$, and $0.660 \%$ of digestible [Met + Cys]), five replications. The control treatment (CT) was performed with the addition of methionine at the first level $(0.264 \%)$ until the second level was reached $(0.396 \%)$. The maintenance requirement was determined by the regression analysis between the consumption of [Met + Cys] and protein retention equal to zero. The efficiency was determined using the value of the slope coefficient of the line obtained by the linear regression. The protein and methionine retention values of tambaqui weighing 100 to $300 \mathrm{~g}$ were compared by the parallelism test, and no difference was observed between the parameters of the equations indicating the need for only one equation to describe the responses to body weights. The requirement of digestible [Met + Cys] for the maintenance of tambaqui with weights from 100 to $300 \mathrm{~g}$ was $60.47 \mathrm{mg} \mathrm{kg}^{-0.7} \mathrm{day}^{-1}$ and the efficiency of utilization of $42 \%$.
\end{abstract}

Index terms: Sulfur amino acids; Colossoma macropomum; factorial method; Amazon fish.

\begin{abstract}
RESUMO
A metionina é um aminoácido essencial e, geralmente, o primeiro limitante em dietas para o tambaqui, principal peixe nativo produzido na aquicultura continental da América do Sul. No entanto, há uma carência de informações sobre suas exigências de aminoácidos, especialmente para mantença e eficiência de utilização. O presente estudo teve como objetivo determinar a exigência de metionina mais cistina para mantença e eficiência de utilização do tambaqui com diferentes pesos corporais. Foram realizados dois experimentos utilizando 250 tambaqui com pesos de 100 e $300 \mathrm{~g}$, distribuídos em delineamento inteiramente casualizado, com quatro tratamentos $(0,264 ; 0,396 ; 0,528$ e $0,660 \%$ de metionina mais cistina digestível) e cinco repetições. Foi realizado um tratamento controle (TC), com adição de metionina no primeiro nível $(0,264 \%)$ até que o segundo nível fosse alcançado (0,396\%). A exigência para mantença foi determinada pela análise de regressão entre o consumo de metionina mais cistina digestível e a retenção de proteína igual a zero, e a eficiência de utilização foi determinada utilizando o valor do coeficiente de inclinação da reta obtida pela regressão linear. A retenção de proteína e metionina dos tambaqui de 100 a $300 \mathrm{~g}$ foram comparados pelo teste de paralelismo e não foi observada diferença entre os parâmetros das equações, indicando a necessidade de apenas uma equação para descrever as respostas aos pesos corporais. Assim, a exigência de metionina mais cistina digestível para mantença do tambaqui com pesos de 100 a $300 \mathrm{~g}$ é de 60,47 mg kg-0,7 dia ${ }^{-1}$ e a eficiência de utilização de $42 \%$.
\end{abstract}

Termos para indexação: Aminoácidos sulfurados; Colossoma macropomum; método fatorial; peixe amazônico. 


\section{INTRODUCTION}

Tambaqui (Colossoma macropomum) is a neotropical fish of great cultural and economic importance for the inhabitants of the Amazon River basin. It is popular among fish farmers owing to its easy handling in all breeding ages, omnivorous feeding habit that allows its use as commercial feed, and good adaptation to the cultivation system in nurseries (Woynárovich; Van Anrooy, 2019). However, there is a lack of information on their nutritional requirements (Guimarães; Martins, 2015).

Methionine is an essential amino acid for fish (National Research Council - NRC, 2011) and is generally the first limiting amino acid in many fish diets, especially those that use vegetable protein sources (Souza et al., 2019). The effect of methionine deficiency on growth and feed efficiency of fish has been demonstrated in several studies (Abidi; Khan, 2011; Tulli et al., 2010) because it participates in protein and choline synthesis and acts as a methyl group donor for nucleic acid and phospholipid substrates (Mato et al., 1997). Cysteine, synthesized from methionine, is readily oxidized to cystine and is considered a semi-essential or conditionally essential amino acid. Owing to the conversion of methionine to cysteine, the requirement is normally expressed as total sulfur amino acids or [Met + Cys] (NRC, 2011).

The technique used to formulate experimental diets can directly affect the productive responses of animals. One such technique, the technique of gradual supplementation of amino acids (D'Mello, 1982), has been criticized due to the successive increase in amino acid levels and the excessive use of synthetic amino acids that can alter the balance with other amino acids in the diet and compromise the productive responses of animals (Siqueira et al., 2013). An alternative technique for formulating experimental diets is the diet dilution technique (Fisher; Morris, 1970). This technique consists of mixing two diets, one containing a high content of the tested amino acid and the other is a protein-free diet (PFD). Thus, a diet is obtained that has intermediate levels of the amino acid tested and reduced levels of industrial amino acids. Siqueira et al. (2013) reported that the use of the diet dilution technique provided more accurate results in the performance of animals than the supplementation technique.

The amino acid requirements of fish have been determined by the dose-response method (Bomfim et al., 2020; Firmo et al., 2018; Souza et al., 2019) that evaluates the response (in function) of the increase in the test amino acid of the diet that maximizes the animal performance (Sakomura; Rostagno, 2016). However, another methodology that has gained prominence in determining the amino acid requirement in fish studies is the factorial method (Abboudi et al., 2006; He et al., 2013; Hua; Suwendi; Bureau, 2019) that determines the need for a nutrient considering the sum of the maintenance requirements plus growth and/or production (Sakomura; Rostagno, 2016).

The maintenance requirement can be understood as the amount of ingested nitrogen necessary to keep the animal in nitrogen balance or when the nitrogen retention is equal to zero. The efficiency of utilization considers the slope of the straight line obtained by the linear regression of amino acid deposition in the body as a function of the amino acid intake (Sakomura; Rostagno, 2016).

A relevant aspect is the effect of body weight on the requirement of amino acids for maintenance and efficiency of utilization of the fish. Some studies with different species of fish were conducted to determine the amino acid requirements for maintenance and efficiency of utilization for different body weights (Hauler; Carter, 2001; He et al., 2013; Hua; Suwendiand; Bureau, 2019). However, studies on amino acid requirements for native fish species that possess commercial potential in Brazil are still scarce.

The objective of this study was to determine the requirement for digestible [Met $+\mathrm{Cys}$ ] for maintenance and efficiency of utilization by tambaqui of different body weights.

\section{MATERIAL AND METHODS}

\section{Experimental}

The two experiments were conducted at the Laboratory of Nutrition and Food of Aquatic Organisms of Maranhão located at the Center for Agricultural and Environmental Sciences of the Federal University of

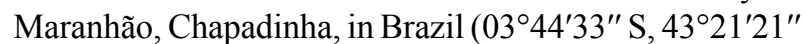
$\mathrm{W}$; altitude $105 \mathrm{~m})$. The experimental procedures were approved by the Animal Use Ethics Committee of the Federal University of Maranhão (Registration Number: 23115.015461/2019-11).

For the study, 250 tambaqui were used, and each experiment had 125 tambaqui; their initial mean weights were $100 \pm 8.41 \mathrm{~g}$ and $300 \pm 42.52 \mathrm{~g}$, respectively. Both experiments were distributed in completely randomized design (CRD) and consisted of four treatments $(0.264$; $0.396 ; 0.528$; and $0.660 \%$ ) of digestible [Met + Cys] in diets) and five replications. Each experiment was performed for a duration of 25 days; this period was sufficient to measure body protein retention accurately. 
During the experimental periods, the fish were kept in polyethylene boxes of $1,000 \mathrm{~L}$ capacity and equipped with individual water supplies, drainage systems, and aeration systems.

The minimum and maximum temperature values during the experimental period were $25.6 \pm 0.3$ and 25.3 $\pm 0.6{ }^{\circ} \mathrm{C}$ in the morning $(8: 00 \mathrm{~h})$ and $27.5 \pm 0.1$ and 27.1 $\pm 0.2{ }^{\circ} \mathrm{C}$ in the afternoon $(16: 00 \mathrm{~h})$, respectively, for each experiment. The temperature was measured daily using a mercury bulb thermometer graduated from 0 to $50^{\circ} \mathrm{C}$. For each experiment, the $\mathrm{pH}$ was maintained in the range of $7.02 \pm 0.3$ and $7.01 \pm 0.2$, dissolved oxygen between 10.80 \pm 0.7 and $10.50 \pm 0.4 \mathrm{mg} / \mathrm{L}$, and total ammonia $\leq 1.00 \mathrm{ppm}$, respectively. These variables were measured daily using a digital $\mathrm{pH}$ meter, oximeter, and commercial colorimetric kit for toxic ammonia testing. The values of the water quality parameters during the two experiments were considered satisfactory for the development of the species (Gomes; Simões; Araújo- Lima, 2020).

\section{Experimental diets}

In order to formulate the experimental diets, the total amino acid contents of corn and soybean meal were analyzed and converted into digestible amino acids for tambaqui (Colossoma macropomum) (Table 1).

The experimental diets were formulated using the dilution technique of diets (Fisher; Morris, 1970).

The ingredients of the experimental diets proteinfree (PDF) based on corn starch, and concentrated diet (CD), contained $25.18 \%$ of crude protein $(\mathrm{CP})$ and $0.660 \%$ of digestible $[\mathrm{Met}+\mathrm{Cys}]$ based on corn and soybean meal (Table 2). Initially, the diet was finely ground (Trf 60 , Trapp $^{\circledR}$ ), weighed individually, and then mixed (Horizontal
Mixer $300 \mathrm{Kg}$, Branorte ${ }^{\circledR}$ ). To obtain intermediate diets (0.264; 0.396 ; and $0.528 \%$ of digestible [Met + Cys]), mixtures were performed by dilution (Table 3 ). Subsequently, they were extruded in the equipment with a 4-5 mm sieve (Extruder model MX 40, Inbramaq ${ }^{\circledR}$, Laboratório de Nutrição e Alimentação de Organismos Aquáticos do Maranhão, Chapadinha, Brazil).

The experimental diets were provided daily during six meal times (08:00, 10:00, 12:00, 14:00, 16:00, and 18:00 h) until apparent satiation. At each meal, they were supplied in small quantities with successive passes, thus allowing maximum intake.

To confirm that digestible [Met + Cys] was the first limiting nutrient, a fifth treatment was carried out (CT: control treatment) with five replications: the addition of synthetic methionine (DL-methionine) in the first level $(0.264 \%)$ until the second level was reached $(0.396 \%)$ (Table 3).

\section{Carcass preparation and analysis}

The comparative slaughter technique was used to study maintenance requirements and efficiency of utilization of [Met + Cys] for tambaqui. At the beginning of each experiment, 15 fish from the population used in each experiment were euthanized $\left(100 \mathrm{mg} \mathrm{L}^{-1}\right.$ benzocaine, after fasting for $\left.24 \mathrm{~h}\right)$ and frozen in an ultra-freezer at $-70{ }^{\circ} \mathrm{C}$ temperature for later determination of the initial body protein content. At the end of the study, after fasting for $24 \mathrm{~h}$, all fish in the experimental units were weighed, euthanized (100 $\mathrm{mg} \mathrm{L}^{-1}$ benzocaine), and frozen in an ultra-freezer with $-70^{\circ} \mathrm{C}$ temperature to determine the final body protein content.

Table 1: Composition, total amino acids (TAA), and digestible (DAA) of corn, soybean meal and corn starch used in experimental diets.

\begin{tabular}{ccccccc}
\hline & \multicolumn{2}{c}{ Corn } & \multicolumn{2}{c}{ Soybean meal } & \multicolumn{2}{c}{ Corn starch } \\
\hline Crude protein (\%) & \multicolumn{2}{c}{7.60} & \multicolumn{2}{c}{46.60} & \multicolumn{2}{c}{--} \\
Gross energy $\left(\mathrm{kcal} \mathrm{kg}^{-1}\right)$ & \multicolumn{2}{c}{3940.00} & \multicolumn{2}{c}{4090.00} & \multicolumn{2}{c}{3821.00} \\
\hline Amino acid (\%) & TAA $^{1}$ & DAA $^{2}$ & TAA $^{1}$ & DAA $^{2}$ & TAA $^{1}$ & DAA $^{2}$ \\
\hline Lysine & 0.30 & 0.27 & 2.91 & 2.75 & -- & -- \\
Methionine & 0.15 & 0.15 & 0.58 & 0.55 & -- & - \\
Methionine + cystine & 0.30 & 0.27 & 1.25 & 1.16 & -- & - \\
Threonine & 0.34 & 0.34 & 1.77 & 1.74 & -- & - \\
Tryptophan & 0.05 & 0.04 & 0.76 & 0.72 & -- & -- \\
\hline
\end{tabular}

${ }^{1}$ Total Amino Acids, determined by high-performance liquid chromatography (HPLC) by the laboratory CBO - Valinhos, SP; ${ }^{2}$ Based on the digestibility coefficients for amino acids obtained by Nascimento et al. (2020) for tambaqui. 
Table 2: Composition of protein-free diet (PFD) and concentrated diet (CD) (natural matter).

\begin{tabular}{ccc}
\hline \multirow{2}{*}{ Ingredients (\%) } & \multicolumn{2}{c}{ Diets } \\
\cline { 2 - 3 } Soybean meal & - & 47.205 \\
Corn & - & 41.235 \\
Corn starch & 81.489 & 2.000 \\
Soy oil & 9.944 & 4.368 \\
Rice husk & 3.477 & - \\
L- Lysine-HCl (78.24\%) & - & 0.341 \\
L-Threonine (98.5\%) & - & 0.359 \\
L- Tryptophan (98,5\%) & - & 0,013 \\
Calcitic limestone & 0.139 & 0.238 \\
Dicalcium phosphate & 3.827 & 3.162 \\
Vitamin e mineral Premix & 0.500 & 0.500 \\
Vitamin C & 0.050 & 0.050 \\
Salt & 0.554 & 0.510 \\
Antioxidant (BHT) & 0.020 & 0.020 \\
\hline Analyzed composition & \\
\hline Crude protein (\%) & - & 25.18 \\
Gross Energy (kcal kg-1) & 4041.74 & 4071.93 \\
Total Lysine (\%) & - & 1.764 \\
Total met + cys (\%) & - & 0.714 \\
Total Threonine (\%) & - & 1.329 \\
Total Tryptophan (\%) & - & 0.392 \\
\hline Vian and mina supp & - & \\
\hline
\end{tabular}

'Vitamin and mineral supplement, amounts supplied per kg of diet: Vit. A, 6,000 IU; Vit. D3, 1,000 IU; Vit. E, 60.0 mg; Vit. K3, 12.0 mg; Vit. B1, 24.00 mg; Vit. B2, 24.00 mg; Vit. B6, 24.00 mg; Vit. B12, $24.00 \mathrm{mg}$; Vit. C, $24.00 \mathrm{mg}$; folic acid, $6.00 \mathrm{mg}$; Ca pantothenate, $60.00 \mathrm{mg}$; biotin, $0.24 \mathrm{mg}$; choline chloride, 108 g; niacin, $100.00 \mathrm{mg}$; Fe, $250.00 \mathrm{mg}$; Cu, $15.0 \mathrm{mg}$; Mn, 100.00 $\mathrm{mg}$; Zn, $150.00 \mathrm{mg}$; I, $0.5 \mathrm{mg}$; Co, $0.05 \mathrm{mg}$; Se, $0.5 \mathrm{mg}$.

${ }^{2}$ Vit. C: Calcium L-Ascorbic acid 2-monophosphate, $42 \%$ of the active ingredient.

Subsequently, the initial and final samples were lyophilized for $72 \mathrm{~h}\left(-50{ }^{\circ} \mathrm{C},-80 \mathrm{kPa}\right)$ in $\mathrm{L} 108$ freezedrying equipment $\left(\mathrm{LIOTOP}^{\circledR}\right)$ and then processed in an analytical mill (IKA ${ }^{\circledR}$ A11 basic).

The crude protein of whole body tambaqui was determined by the standard method (Association of Official Analytical Chemists - AOAC, 2019), and the percentage of nitrogen was obtained by the Kjeldahl method after acid digestion.

The analysis of the [Met + Cys] content of the whole body of tambaqui was performed using high- performance liquid chromatography (HPLC) at the CBO laboratory (Valinhos, Brazil).

\section{Evaluated variables}

The variables evaluated were feed intake (FI; $g$ fish ${ }^{-1}$ day $^{-1}$ ), digestible [Met + Cys] consumption (DMCC; $\mathrm{mg}$ $\mathrm{kg}^{-0.7}$ day $^{-1}$ ), final weight (FW; g), weight gain (WG;\%), body protein retention (BPR; $\mathrm{g} \mathrm{kg}^{-0.7}$ day $^{-1}$ ), and body methionine + cystine retention (BMCR; $\mathrm{mg} \mathrm{kg}^{-0.7}$ day $\left.^{-1}\right)$ :

$\mathrm{FI}\left(\mathrm{g}_{\text {fish }}{ }^{-1}\right.$ day $\left.^{-1}\right)=$ Feed consumption period $(\mathrm{g}) / \mathrm{N}^{\mathrm{o}}$ fish $/ \mathrm{N}^{\mathrm{o}}$ experiment days $\operatorname{DMCC}\left(\mathrm{mg} \mathrm{Kg}^{-0.7}\right.$ day $\left.^{-1}\right)=\frac{\mathrm{FI}(\mathrm{g}) \times \text { digestible met. }+ \text { cys. in the feed }(\%) / 100}{\mathrm{FW}\left(\mathrm{Kg}^{-0.7} \text { day }^{-1} / \mathrm{N}^{\circ} \text { experiment days }\right.}$ WG $(\%)=$ Final weight $(\mathrm{g})$ - Initial weight $(\mathrm{g}) /$ Initial weight $(\mathrm{g}) \times 100$ $\operatorname{BPR}\left(\mathrm{gKg}^{-0.7} \mathrm{day}^{-1}\right)=\frac{(\text { Final body protein }(\%) \times \mathrm{FW}(\mathrm{g})-(\text { initial body protein }(\%) \times \text { initial weight }(\mathrm{g}))}{\text { experiment period } / \text { final weight }\left(\mathrm{Kg}^{-0.7}\right) / 100}$

The BMCR was obtained by multiplying the content of [Met + Cys] of tambaqui body ( $\%$ of crude protein) by body protein deposition, and dividing this value by weight final ${ }^{-0.7}$; this represents the metabolic weight for fish used in several studies (Grisdale-Helland et al., 2011; Helland; Hatlen; Grisdale-Helland, 2010; He et al., 2013).

The values of [Met + Cys] were obtained by an aminogram (HPLC analysis) and converted into a percentage of the tambaqui's body crude protein, which corresponded to the value of $3.91 \%$; it was calculated using the following formulas:

Met + Cys in protein $(\%)=\frac{\{\text { Met }+ \text { Cys analysis values } x \text { tambaqui's body crude protein } \%\}}{100 \%}$ $\operatorname{BMCR}\left(\mathrm{mg} \mathrm{Kg}^{-0.7}\right.$ day $\left.^{-1}\right)=\frac{\{(\text { Body protein deposition }(\%) \times \text { Met }+ \text { Cys in protein }(\%)) / 100\}}{\text { Final weight }\left(\mathrm{Kg}^{-0.7}\right)}$

To determine the requirement of digestible [Met + Cys] for maintenance, a regression analysis was performed between the consumption of methionine plus digestible cystine $\left(\mathrm{mg} \mathrm{kg}^{-0.7}\right.$ day $\left.^{-1}\right)$ and the retention of body protein $\left(\mathrm{g} \mathrm{kg}^{-0.7} \mathrm{day}^{-1}\right)$. The requirement of digestible [Met + Cys] for maintenance of tambaqui was considered when consumption of digestible [Met + Cys] provided protein retention equal to zero (He et al., 2013). The efficiency of utilization of digestible [methionine plus cystine] for growth was determined using the value of the slope coefficient of the straight line, obtained through the regression analysis between the consumption of digestible [Met + Cys] $\left(\mathrm{mg} \mathrm{kg}^{-0.7} \mathrm{day}^{-1}\right)$ and the retention of [Met + Cys] (mg kg ${ }^{-0.7}$ day $\left.^{-1}\right)$ (Hua; Suwendi; Bureau, 2019). 
Table 3: Experimental diets elaborated by diet dilution technique (natural matter)

\begin{tabular}{|c|c|c|c|c|c|}
\hline \multirow{2}{*}{ Diets (\%) } & \multicolumn{5}{|c|}{ Digestible Met + Cys Levels (\%) } \\
\hline & 0.264 & 0.396 & 0.528 & 0.660 & $\mathrm{CT}^{*}$ \\
\hline \multicolumn{6}{|c|}{ Dilution (\%) } \\
\hline PFD & 60.00 & 40.00 & 20.00 & - & 60.00 \\
\hline$C D$ & 40.00 & 60.00 & 80.00 & 100.00 & 40.00 \\
\hline Total & 100.00 & 100.00 & 100.00 & 100.00 & 100.00 \\
\hline \multicolumn{6}{|c|}{ Analyzed composition ${ }^{1}$} \\
\hline Crude protein $(\%)^{1}$ & 10.07 & 15.11 & 20.14 & 25.18 & 10.07 \\
\hline Digestible protein $(\%)^{2}$ & 9.16 & 13.74 & 18.32 & 22.90 & 9.16 \\
\hline Gross Energy $\left(\mathrm{kcal} \mathrm{kg}^{-1}\right)^{1}$ & 4053.82 & 4059.85 & 4065.89 & 4071.93 & 4053.82 \\
\hline Digest. Energy $\left(\mathrm{kcal} \mathrm{kg}^{-1}\right)^{3}$ & 3000.00 & 3000.00 & 3000.00 & 3000.00 & 3000.00 \\
\hline Total met + cys $(\%)^{1}$ & 0.286 & 0.428 & 0.571 & 0.714 & 0.286 \\
\hline Digestible met + cys $(\%)^{2}$ & 0.264 & 0.396 & 0.528 & 0.660 & 0.396 \\
\hline Total Lysine (\%) & 0.710 & 1.058 & 1.411 & 1.764 & 0.710 \\
\hline Digestible Lysine $(\%)^{2}$ & 0.672 & 1.008 & 1.344 & 1.680 & 0.672 \\
\hline Total Threonine (\%)' & 0.535 & 0.847 & 1.129 & 1.329 & 0.535 \\
\hline Digestible Threonine(\%) ${ }^{2}$ & 0.523 & 0.785 & 1.047 & 1.308 & 0.523 \\
\hline Total Tryptophan (\%)1 & 0.157 & 0.239 & 0.315 & 0.392 & 0.157 \\
\hline Digestible Tryptophan(\%) & 0.148 & 0.221 & 0.295 & 0.369 & 0.148 \\
\hline
\end{tabular}

${ }^{*} \mathrm{CT}$ : Control Treatment $(0.396 \%$ met + cys.);

${ }^{1}$ Crude fiber, 3.22\%; Digestible met. + cyst./lysine ratio, 39\%; Digestible threonine/lysine ratio, 77\%; Digestible tryptophan/lysine ratio, 22\%; Phosphorus available, 0.60\%; Total calcium, $1.20 \%$; Total sodium, $0.22 \%$. ${ }^{2}$ Based on the digestibility coefficients for amino acids obtained by Nascimento et al. (2020) ${ }^{3}$ Based on the digestibility coefficients of energy and protein for corn starch, corn, soybean meal and soy oil obtained by Furuya (2010).

\section{Statistical analyses}

All analyses were performed with the aid of the SAS software (Statistical Analysis System, version 9.0, 2002), considering a significance level of up to $5 \%$.

The data obtained in each experiment were submitted to analysis of variance. Linear regression analysis was performed for variables that affected the results like weight gain (WG), feed intake (FI), digestible [Met + Cys] consumption (DMCC), body protein retention (BPR), and body [Met + Cys] retention (BMCR) as a function of levels of digestible [Met $+\mathrm{Cys}]$ in diets.

To assess the influence of body weight on the maintenance and efficiency of utilization of digestible [Met + Cys] for tambaqui, the protein and [Met + Cys] retention data were compared using a parallelism test (Kaps; Lamberson, 2004); body weight was the categorical variable and DMCC $\left(\mathrm{mg} \mathrm{kg}^{-0.7} \mathrm{day}^{-1}\right)$ was the covariate in the model:
$\mathrm{Y} i j=\beta_{0}+\mathrm{BW} i+\beta_{1}^{*} \mathrm{DMCC} i j+\Sigma i \beta_{2} i(\mathrm{BW} * \mathrm{DMCC}) i j+\mathrm{e}_{\mathrm{ij}} ;$

where $\mathrm{Y} i j=$ Body protein (BPR) or methionine plus cystine retention (BMCR) corresponds to observation $\mathrm{j}$ body weight $\mathrm{i}$; BW $i=$ body weight effect; $\beta 0, \beta 1 \mathrm{e}$ $\beta 2 \mathrm{i}=$ regression parameters; $\left(\mathrm{BW}^{*} \mathrm{DMCC}\right) i j=$ effect of intention between the categorical variable and the covariate; and $\varepsilon i j=$ random error associated with observation $\mathrm{j}$ body weight $\mathrm{i}$.

In this case, the tested hypotheses were:

a) $\mathrm{H} 0: \mathrm{Gi}=0$ for all $\mathrm{i}$, there is no effect on body weight.

H1: $\mathrm{Gi} \neq 0$ for at least one $\mathrm{i}$; there is an effect of body weight;

b) H0: $\beta 1=0$, general slope is zero, non-significant regression;

$\mathrm{H} 1: \beta 1 \neq 0$, the overall slope differs from zero, significant regression;

c) $\mathrm{H} 0: \beta 2 \mathrm{i}=0$, the inclination of body weight i does not differ from the average inclination. 


\section{RESULTS AND DISCUSSION}

There was no mortality during the experimental periods nor were any external pathological signs observed, even in animals fed the lowest [Met + Cys] level.

Weight gain showed a linear increase $(\mathrm{p}<0.05)$ in the animals weighing $300 \mathrm{~g}$. The lowest weight gain was observed in fish fed on the lowest level of digestible [Met + Cys] $(0.264 \%)$ due to the lower consumption of digestible [Met + Cys] (DMCC) by animals. Moreover, the weight gain in tambaqui was influenced by increasing the levels of digestible [Met $+\mathrm{Cys}]$ in the diets for the evaluated body weights; the highest weight gain (29.94\%) was obtained by the $300 \mathrm{~g}$ animals fed on the highest content of methionine plus the digestible cystine $(0.660 \%)$ (Table 4$)$.

Weight gain has been used to determine the requirement for amino acids in dose-response studies (Bomfim et al., 2020; Firmo et al., 2018; Souza et al., 2019). However, it is not considered a reliable variable to determine the requirement of amino acids for maintenance or growth, considering that fish can gain weight in the form of body protein, water, fat, and to a lesser extent minerals (Sakomura; Rostagno, 2016; Sousa et al., 2018).

Deposition of body protein is a more accurate variable to assess the deficiency of amino acids in the diet since amino acids are the basic components of protein and the deficiency of one of the amino acids in the diet reduces protein synthesis (Grisdale-Helland et al., 2011). Thus, this variable is more accurate to determine the requirement of digestible [Met + Cys] for the maintenance of tambaqui. Moreover, Emmans and Fisher (1986) demonstrated that the amino acid requirements for maintenance are more closely related to the body protein content because of the lack of demand for amino acids to maintain lipid reserves.

The feed intake showed a linear reduction $(p<0.05)$ in both experiments indicating that the animals increased their consumption in the lower levels to compensate for the deficiency of the test amino acid in the diets. However, the consumption of digestible [Met + Cys] in the experiments showed a linear increase ( $p$ $<0.05$ ) (Table 5).

Retention of body protein and [Met + Cys] showed a linear increase $(\mathrm{p}<0.05)$ with an increase in the level of digestible $[\mathrm{Met}+\mathrm{Cys}]$ in the diet for each experiment. The results obtained for the retention of body protein and retention of [Met $+\mathrm{Cys}]$ for the animals subjected to the control treatment $(0.396 \%$ [Met + Cys] and $10.07 \% \mathrm{CP})$ were higher than the lowest level of the digestible [Met + Cys] tested $(0.264 \%$ [Met + Cys] and $10.07 \% \mathrm{CP})$ in both experiments. This indicated that methionine was the limiting essential amino acid and not the protein values in the diets (Table 5).

The diets provided to the fish allowed sufficient interval for the values of protein and [Met + Cys] retention to become negative, close to zero, and positive. This enabled the estimation of the maintenance requirement and the utilization of efficiency without the need for extrapolations (Table 5).

Table 4: Initial average weight, final average weight, and weight gain (WG) of tambaqui fed on different diets.

\begin{tabular}{ccccc}
\hline \multirow{2}{*}{ Body weight } & $\begin{array}{c}\text { Digestible Met }+ \text { Cys } \\
\text { Levels (\%) }\end{array}$ & \multicolumn{2}{c}{ Average weight (g) } & \multirow{2}{*}{ Weight gain (\%) } \\
\cline { 2 - 4 } & 0.264 & $101.00 \pm 0.77$ & $124.05 \pm 2.67$ & $22.82 \pm 2.52$ \\
\multirow{3}{*}{$100 \mathrm{~g}$} & 0.396 & $102.07 \pm 0.30$ & $128.13 \pm 2.79$ & $25.51 \pm 2.50$ \\
& 0.528 & $100.49 \pm 0.45$ & $126.33 \pm 3.47$ & $29.09 \pm 3.58$ \\
& 0.660 & $101.91 \pm 0.30$ & $129.97 \pm 3.06$ & $27.52 \pm 2.83$ \\
\hline \multirow{3}{*}{$300 \mathrm{~g}$} & $101.09 \pm 0.65$ & $127.23 \pm 1.22$ & $25.89 \pm 1.70$ \\
\hline & 0.264 & $304.86 \pm 0.84$ & $367.75 \pm 5.84$ & $20.63 \pm 1.82$ \\
& 0.396 & $305.09 \pm 1.42$ & $373.78 \pm 2.77$ & $25.53 \pm 3.24$ \\
& 0.528 & $304.63 \pm 1.18$ & $370.72 \pm 8.74$ & $21.67 \pm 2.59$ \\
& 0.660 & $303.21 \pm 0.42$ & $393.98 \pm 4.91$ & $29.94 \pm 1.71$ \\
\hline
\end{tabular}

${ }^{1}$ CT: Control Treatment $(0.396$ met + cys.);

${ }^{2}$ Linear effect; Animals 300g: $W G=16.299+17.896 \mathrm{Met}\left(\mathrm{p}<0.031 ; r^{2}=0.54\right)$,

WG $(\%)=($ Final weight $(\mathrm{g})-$ Initial weight $(\mathrm{g}))$ / Initial weight $(\mathrm{g}) \times 100$;

The values presented correspond to the mean ( \pm standard error) of 20 fish for each body weight evaluated in each treatment. 
In addition, body protein retention data were subjected to regression analysis as a function of digestible [Met $+\mathrm{Cys}$ ] consumption. The maintenance requirement value for animals weighing $100 \mathrm{~g}$ was $58.89 \mathrm{mg} \mathrm{kg}^{-0.7}$ day $^{-1}$ according to the equation: $\mathrm{BPR}=$ $0.009 * \mathrm{DMCC}-0.53\left(\mathrm{p}<0.0001 ; \mathrm{r}^{2}=0.916\right)$. The value for animals weighing $300 \mathrm{~g}$ was $61.23 \mathrm{mg} \mathrm{kg}^{-0.7}$ day $^{-1}$ according to the equation: $\mathrm{BPR}=0.0124 * \mathrm{DMCC}-$ $0.7593\left(p<0.0001 ; r^{2}=0.7513\right)$ (Figure 1a, where $\mathbf{a}$ for animals weighing $100 \mathrm{~g}$ and $\mathbf{a}$ for animals of control

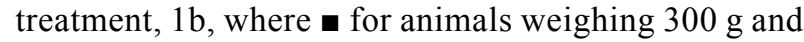
a for control treatment animals).

The data were subjected to the parallelism test (Kaps; Lamberson, 2004) to verify the effect of body weight on individual maintenance requirement values for each experiment no difference $(p>0.05)$ was detected between the parameters of the equations. This indicated that the equation $\mathrm{BPR}=0.0107( \pm 0.0010)-0.647(0.0761) *$ DMCC $\left(\mathrm{p}<0.0001 ; \mathrm{r}^{2}=0.7758\right)$ described the body weight responses from 100 to $300 \mathrm{~g}$ (Figure 2) satisfactorily.

Table 5: Feed intake (FI), digestible [methionine plus cystine] consumption (DMCC), body protein retention (BPR) and body [methionine plus cystine] retention (BMCR) of tambaqui fed different diets.

\begin{tabular}{cccccc}
\hline \multirow{2}{*}{ Body weight } & $\begin{array}{c}\text { Digestible Met } \\
\text { Cys Levels (\%) }\end{array}$ & $\mathrm{Fl}^{*}$ & $\mathrm{DMCC}^{*}$ & $\mathrm{BPR}^{*}$ & $\mathrm{BMCR}^{*}$ \\
\cline { 3 - 6 } & 0.264 & $5.16 \pm 0.43$ & $58.49 \pm 4.06$ & $-0.02 \pm 0.04$ & $-0.66 \pm 1.71$ \\
\multirow{3}{*}{$100 \mathrm{~g}$} & 0.396 & $4.06 \pm 0.29$ & $67.55 \pm 3.89$ & $0.11 \pm 0.04$ & $4.30 \pm 1.64$ \\
& 0.528 & $4.09 \pm 0.38$ & $89.83 \pm 6.49$ & $0.18 \pm 0.02$ & $7.01 \pm 0.71$ \\
& 0.660 & $3.53 \pm 0.22$ & $96.88 \pm 4.51$ & $0.36 \pm 0.05$ & $14.01 \pm 1.85$ \\
\hline \multirow{3}{*}{$300 \mathrm{~g}$} & $\mathrm{CT}^{1}$ & $5.63 \pm 0.17$ & $94.42 \pm 2.38$ & $0.12 \pm 0.03$ & $4.57 \pm 1.09$ \\
& 0.264 & $9.07 \pm 0.51$ & $48.16 \pm 2.16$ & $-0.25 \pm 0.02$ & $-9.66 \pm 0.76$ \\
& 0.396 & $8.67 \pm 0.46$ & $67.12 \pm 2.33$ & $0.16 \pm 0.08$ & $6.14 \pm 3.22$ \\
& 0.528 & $7.37 \pm 0.30$ & $77.94 \pm 2.68$ & $0.17 \pm 0.05$ & $6.71 \pm 1.93$ \\
& 0.660 & $7.73 \pm 0.43$ & $97.86 \pm 5.32$ & $0.47 \pm 0.04$ & $18.27 \pm 1.49$ \\
\hline
\end{tabular}

${ }^{1} \mathrm{CT}$ : Control Treatment $(0.396 \%$ met + cys. $)$;

* Linear effect; Animals 100g: FI = -3.6834Met. + 5.9111 $\left(p<0.0053 ; r^{2}=0.8414\right), D M C C=104.1424 M e t+30.0742\left(p<0.0001 ; r^{2}=\right.$ 0. 9589); $B P R=0.9091$ Met-0.2600 $\left(p<0.0001 ; r^{2}=0.9716\right) ; B M C R=35.6418$ Met-10.2219 $\left(p<0.0001 ; r^{2}=0.9716\right) ;$ Animals 300g: $\mathrm{FI}=-4.0462 \mathrm{Met} .+10.081\left(\mathrm{p}<0.0135 ; r^{2}=0.7528\right) ; \mathrm{DMCC}=121.1682 \mathrm{Met}+16.7938\left(p<0.0001 ; r^{2}=0.9016\right) ; B P R=1.5631$ Met$0.5754\left(p<0.0001 ; r^{2}=0.9046\right) ; B M C R=60.9154$ Met. $-22.4479\left(p<0.0001 ; r^{2}=0.9016\right)$;

The values presented for animals of $100 \mathrm{~g}$ and $300 \mathrm{~g}$ correspond to the averages ( \pm standard error) of 25 fish each. For the control treatment correspond to the average ( \pm standard error) of 25 fish for animals of 100 and $300 \mathrm{~g}$.
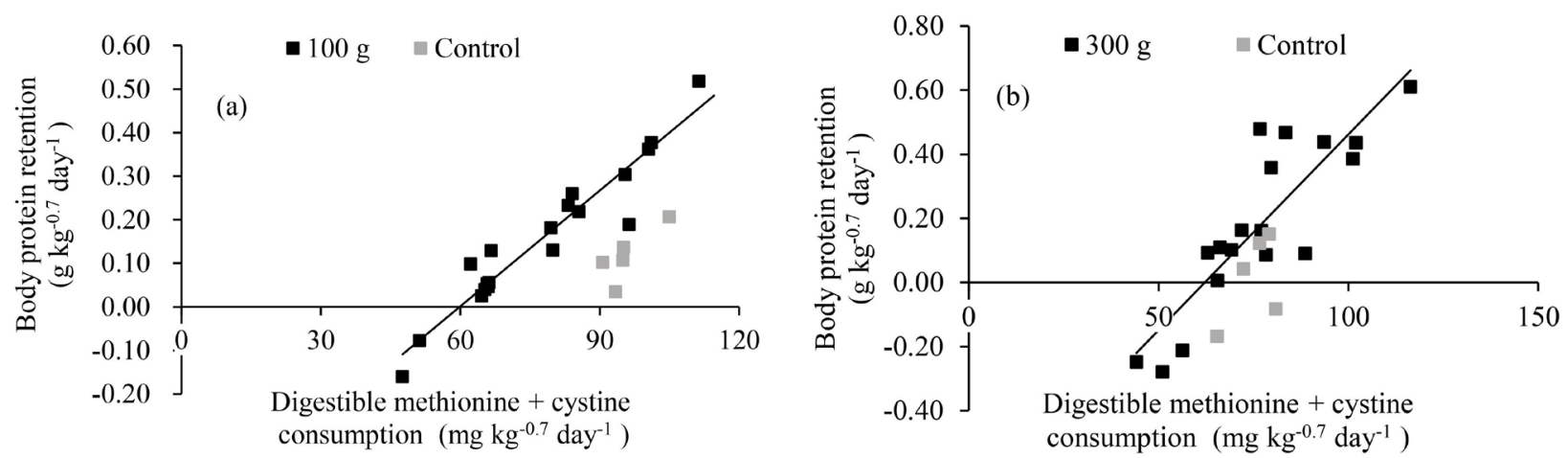

Figure 1: Linear regression for the body protein retention as a function of digestible [Met + Cys] consumption for tambaqui with body weight of $100 \mathrm{~g}(\mathrm{a})$ and $300 \mathrm{~g}(\mathrm{~b})$. 


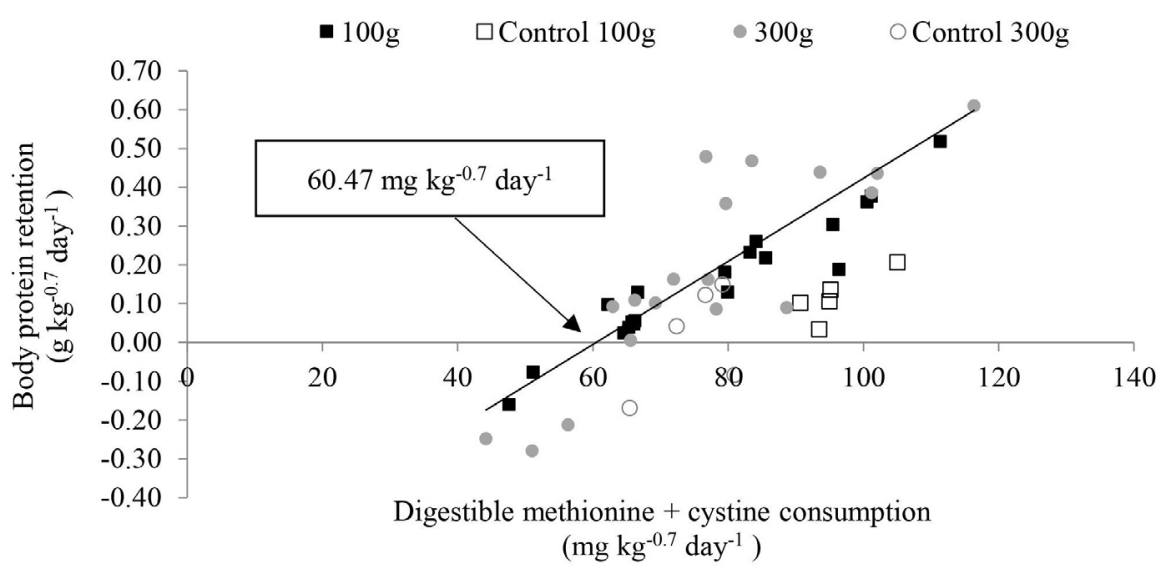

Figure 2: Linear regression for the body protein retention as a function of digestible [Met + Cys] consumption for tambaqui (100 to $300 \mathrm{~g}$ ).

The maintenance requirement of an amino acid can be calculated from the relationship between the intake of the concerned amino acid and the deposition of protein (nitrogen)/amino acid and obtaining a linear response (Abboudi et al., 2006; NRC, 2011). The value of maintenance requirements of digestible [Met $+\mathrm{Cys}$ ] for tambaqui (100 to $300 \mathrm{~g}$ ) was $60.47 \mathrm{mg} \mathrm{kg}^{-0.7} \mathrm{day}^{-1}$ for protein retention equal to zero (Figure 2).

Studies on requirements of maintenance of digestible [Met + Cys] for tambaqui are scarce in the literature. Moreover, the relationship between weight and maintenance requirements is still unclear for this animal. In the present study, no difference was detected between the parameters of the protein retention equations for the two body weights. Thus, there is no effect of body weight on the maintenance requirements for tambaqui weighing from $100 \mathrm{~g}$ to $300 \mathrm{~g}$. The tambaqui is a very robust fish and reaches a maximum weight of around $40 \mathrm{~kg}$ (Woynárovich; Van Anrooy, 2019). Therefore, animals weighing $100 \mathrm{~g}$ to $300 \mathrm{~g}$ may represent minute differences in the weight on the growth curve of this species.

He et al. (2013) determined the requirements of lysine and methionine for the maintenance of Nile tilapia with body weights of 20.7 and $165 \mathrm{~g}$. They observed an increase in the values of the maintenance requirements with increasing body weight. The maintenance requirement values of $3.12 \mathrm{mg} \mathrm{kg}^{-0.7}$ day $^{-1}$ for tilapia weighing $20.7 \mathrm{~g}$ and that of $16.5 \mathrm{mg} \mathrm{kg}^{-0.7}$ day $^{-1}$ for tilapia weighing $165 \mathrm{~g}$ are below the value $\left(60.47 \mathrm{mg} \mathrm{kg}^{-0.7}\right.$ day $\left.^{-1}\right)$ obtained in the current study. This divergence may be related to the age of the animals. In younger animals, the amino acid requirements for the maintenance of the body represent a small fraction of the total requirements, but this situation is reversed as the animal increases in size (Bonato et al., 2011).

Protein deposition occurs at a higher rate in the early stages of animal life compared to that in adults. Therefore, caution is needed while determining the requirement of amino acids for maintenance in early life, as the relationship between the amino acids destined for maintenance and growth changes rapidly with the growth rate of the animal (Abboudi et al., 2006).

In addition to the weight and age of the animals, the study of genetic improvement of tilapia was undertaken over the years to obtain greater feed efficiency, and consequently, less demand for [Met + Cys] for maintenance in a short period (Silva et al., 2018). Currently, genetic improvement programs that explore the zootechnical performance of tambaqui are scarce. Therefore, animals with lower production potential are used as compared to species such as the Nile tilapia and Atlantic salmon (Ponzoni et al., 2005). This can be demonstrated by the values of feed conversion rate (FCR) for Nile tilapia found in the literature that vary from 1.04 to $2.09 \mathrm{~g} \mathrm{~g}^{-1}$ (Iqbal et al., 2020; Michelato et al., 2016; Nguyen, et al., 2019); the values confirm a greater efficiency of tilapia in utilizing food as compared to tambaqui. For tambaqui juveniles, the FCR values range from 1.79 to $3.90 \mathrm{~g} \mathrm{~g}^{-1}$, according to studies by (Araújo et al., 2016) and (Souza Costa et al., 2020), respectively. This lesser feeding efficiency of tambaqui reflects a higher requirement for the maintenance of amino acids by this species.

The experimental period is a factor that interferes with the variation of the maintenance values of amino acids. When the experimental period is longer, e.g., greater than 30 days, metabolic adaptation and changes in maintenance conditions can occur (Abboudi et al., 2006). 
In this study, each experiment lasted 25 days; this period was enough to guarantee changes in the deposition of body protein content (retained nitrogen) and determine the requirement for the maintenance of $[\mathrm{Met}+\mathrm{Cys}]$ for tambaqui.

To study the efficiency of utilization of amino acids, this is an important tool for the elaboration of lowcost diets and lower production of nitrogen compounds in the aquatic environment. Methionine is one of the limiting amino acids in practical diets, especially when plant-based foods are used. Moreover, the results obtained from the efficiency of utilization of [Met + Cys] may contribute to a better understanding of the use of this amino acid for tambaqui. Such factorial models are increasingly used to estimate the essential amino acid requirements of fish (Abboudi et al., 2006; Hauler; Carter, 2001; He et al., 2013; Hua; Suwendi; Bureau, 2019; NRC, 2011).

To estimate the efficiency of utilization of [Met + Cys], the retention data of [Met + Cys] were subjected to regression analysis according to the consumption of digestible [Met + Cys]. A utilization efficiency of 35.15\% was obtained for animals weighing $100 \mathrm{~g}$ according to the equation: $\mathrm{BMCR}=0.3515^{*} \mathrm{DMCC}-20.724$ $\left(\mathrm{p}<0.0001 ; \mathrm{r}^{2}=0.916\right)$. For animals weighing $300 \mathrm{~g}$, this efficiency was $48.47 \%$ according to the equation: $\mathrm{BMCR}=0.4847 * \mathrm{DMCC}-29.69\left(\mathrm{p}<0.0001 ; \mathrm{r}^{2}=0.7513\right)$ as represented in Figure $3 \mathrm{a}$ and $3 \mathrm{~b}$.

The maintenance data and the efficiency of the use of each experiment were subjected to a parallelism test ( $p$ > 0.05) (Kaps; Lamberson, 2004), and there was no effect of body weight on the efficiency of utilization. This efficiency was estimated as $42 \%$ through the slope coefficient of the line of [Met $+\mathrm{Cys}]$ retention as a function of digestible [Met + Cys] consumption and is described by the equation: $\mathrm{BMCR}=0.4188( \pm 0.0381) * \mathrm{DMCC}-25.296$ $( \pm 2.9712)\left(p<0.0001 ; r^{2}=0.7758\right)($ Figure 4$)$.

The fact that there was no difference in the efficiency of utilization of [Met + Cys] for different body weights corroborates the observations of Hauler and Carter (2001). They used the factorial model and observed that the efficiency of utilization of lysine remained constant throughout the life stages of the Atlantic salmon. However, Hua, Suwendi and Bureau (2019) suggested that the factorial models should incorporate the effect of body weight on the efficiency of utilization of lysine.

The results obtained in this study differ from those observed by He et al. (2013) where in they found that the efficiency of utilization of methionine decreased from $76 \%$ to $55 \%$ in a study with Nile tilapia with body weights of 24.7 and $165 \mathrm{~g}$, respectively. For Atlantic salmon (Salmo salar), Grisdale-Helland et al. (2011) determined the efficiency of methionine use to be $69 \%$ for animals weighing 62.8 g. Helland, Hatlen and Grisdale-Helland (2010) obtained an efficiency of 53\% for animals weighing 95.7 g. A similar effect was also observed by Hua, Suwendi and Bureau (2019) using lysine for tilapia with three different weights: small $(9.8 \mathrm{~g})$, medium $(58.1 \mathrm{~g})$, and large $(247.6 \mathrm{~g})$; the estimated efficiencies of utilization were 68,63 , and $47 \%$, respectively.

The low value of efficiency of utilization of [Met + Cys] $(42 \%)$ for tambaqui, in comparison with other species, may be related to the use of the largest proportion of its amino acid requirements in maintenance (body tissue renewal, inevitable catabolism, and fecal losses) and thus resulting in less efficiency of utilization of the dietary amino acids for growth.
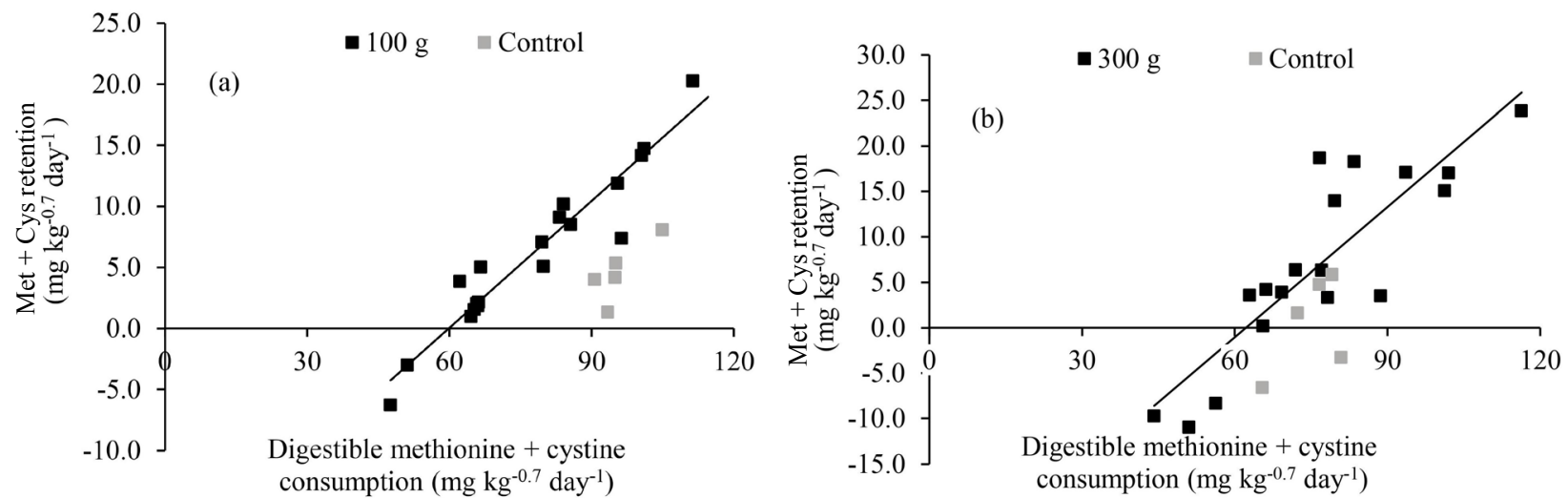

Figure 3: Linear regression for the [Met + Cys] retention as a function of digestible [Met + Cys] consumption for tambaqui with body weight of $100 \mathrm{~g}(\mathrm{a})$ and $300 \mathrm{~g}(\mathrm{~b})$. 


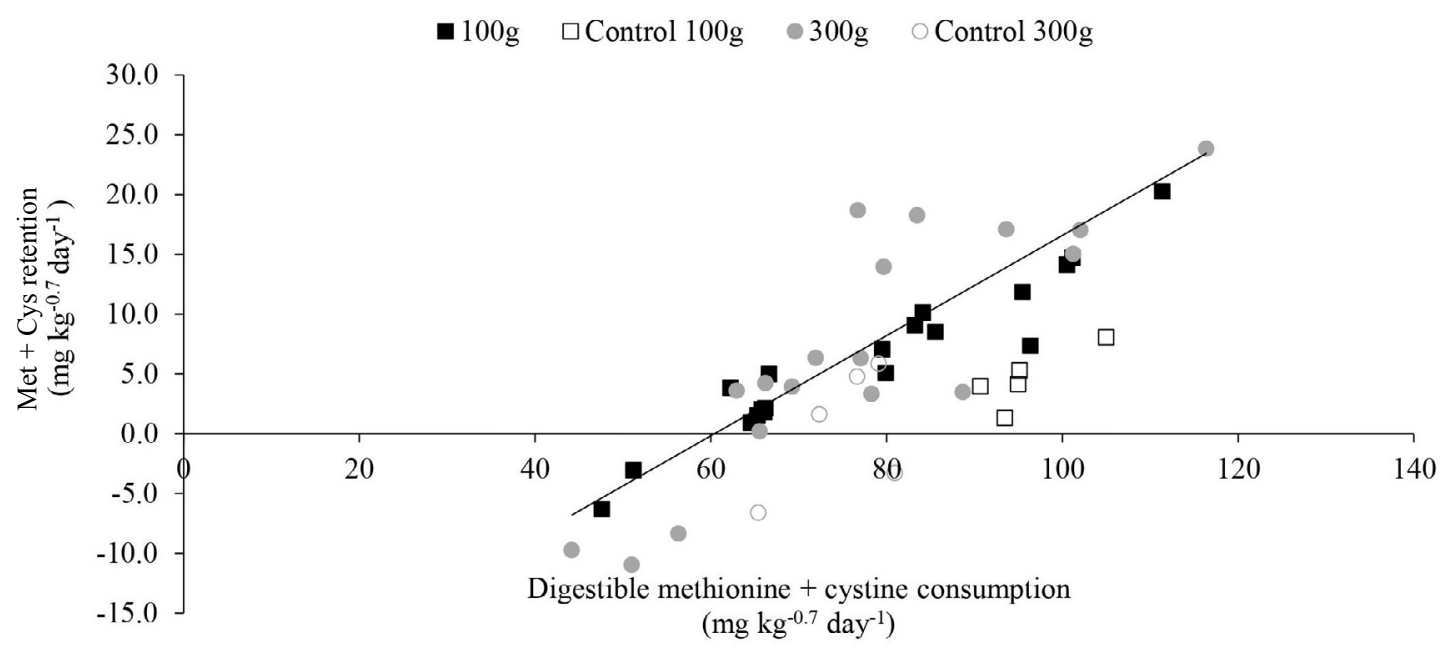

Figure 4: Linear regression for the [Met + Cys] retention as a function of digestible methionine plus cystine consumption for tambaqui with body weight of $100 \mathrm{~g}$ and $300 \mathrm{~g}$.

Morphometrically similar species with the same food habits may differ in their use of amino acids and growth rates (NRC, 2011). Tambaqui can be considered a slow-growing species when compared to other fastgrowing ones like the Nile tilapia and Atlantic salmon. This can be confirmed with recent values of specific growth rate (SGR) found in the literature for juvenile tambaqui as observed in the studies by Araújo et al. (2016) (SGR of $0.86-1.02 \%$ day $^{-1}$ ), Buzollo et al. (2019) (SGR of $1.76-$ 2.74\% day ${ }^{-1}$ ), and Souza Costa et al. (2020) (SGR of 0.2 $-0.6 \%$ day $\left.^{-1}\right)$. The SGR values may vary depending on the experimental conditions of each study. For fast-growing fish like the Nile tilapia, the present SGR ranged from 2.27 to $5.56 \%$ day $^{-1}$ (Figueiredo-Silva et al., 2015; He et al., 2017; He et al., 2020). Fast-growing species allocate a greater fraction of their amino acid requirements for body protein deposition, and consequently, have greater efficiency of utilization of amino acids (Helland; Hatlen; Grisdale-Helland, 2010; He et al., 2013; Hua; Suwendi; Bureau, 2019).

The values obtained in the present study of [Met + Cys] requirements for maintenance and utilization efficiency for tambaqui are crucial for understanding the basal metabolic requirements of amino acids and will help in allowing the production of tambaqui at a minimal cost. Additionally, this research will serve as a basis for nutrition studies on tambaqui since there are no studies on the maintenance and efficiency of utilization of [Met + Cys]. The study will also enable the development of effective factorial models to determine the nutritional requirements of the species.

\section{CONCLUSIONS}

The requirement for digestible [Met + Cys] for maintenance and efficiency of utilization is $60.47 \mathrm{mg} \mathrm{kg}^{-0.7}$ day $^{-1}$ and $42 \%$, respectively, for tambaqui in the weight ranges of 100 to $300 \mathrm{~g}$.

\section{ACKNOWLEDGEMENTS}

The Fundação de Amparo à Pesquisa e ao Desenvolvimento Científico e Tecnológico do Maranhão (FAPEMA) for project financing. This study was financed in part by the Coordenação de Aperfeiçoamento de Pessoal de Nível Superior - Brasil (CAPES) - Finance Code 001.

\section{REFERENCES}

ABBOUDI, T. et al. Protein and lysine requirements for maintenance and for tissue acretion in Atlantic salmon (Salmo salar) fry. Aquaculture, 261(1):369383, 2006.

ABIDI, S. F.; KHAN, M. A. Total sulphur amino acid requirement and cysteine replacement value for fingerling rohu, Labeo rohita: Effects on growth, nutrient retention and body composition. Aquaculture Nutrition. 17(2):e583-594, 2011.

ARAÚJO J. G. et al. Dietary available phosphorus requirement for tambaqui, Colossoma macropomum, juveniles based on growth, haematology and bone mineralization. Aquaculture Nutrition, 23(4):822-832, 2016. 
ASSOCIATION OF OFFICIAL ANALYTICAL CHEMISTS - AOAC. Official methods of analysis. 21.ed. Rockville, MD.: AOAC, 2019. 3390p.

BOMFIM, M. A. D. et al. Digestible tryptophan requirement for tambaqui (Colossoma macropomum) fingerlings. Revista Ciência Agronômica, 51(2):e20196724, 2020.

BONATO M. A. et al. Maintenance requirements for methionine and cysteine, and threonine for poultry. South African Journal of Animal Science, 41(3):209-22, 2011.

BUZOLLO, H. et al. Digestible protein requirements and muscle growth in juvenile tambaqui (Colossoma macropomum). Aquaculture Nutrition, 25(3):669-679, 2019.

D'MELLO, J. P. F. A comparison of two empirical methods of determining amino acid requirements. World's Poultry Science Journal, 38(2):114-119, 1982.

EMMANS, G. C.; FISHER, C. Problems in nutritional theory. In: FISHER, C.; BOORMAN, K. N. (Eds.) Nutrient requirements of poultry and nutritional research. London: Butterworths, p.9-39, 1986.

FIGUEIREDO-SILVA, C. et al. Effect of DL- methionine supplementation on the success of almost total replacement of fish meal with soybean meal in diets for hybrid tilapia (Oreochromis niloticus $\times$ Oreochromis mossambicus). Aquaculture Nutrition, 21(2):234-241, 2015.

FIRMO, D. S. et al. Threonine to lysine ratio in diets of tambaqui juveniles (Colossoma macropomum). Semina: Ciências Agrárias, 39(5):2169-2180, 2018.

FISHER, C.; MORRIS, T. R. The determination of the methionine requirements of laying pullets by a diet dilution technique. British Poultry Science, 11(1):67-82, 1970.

FURUYA, W. M. Tabelas brasileiras para nutrição de tilápias. Toledo: GFM, 2010. 100p.

GOMES, L. C.; SIMÕES, L, N.; ARAÚJO- LIMA, C. A. R. M. Tambaqui (Colossoma macropomum). In: BALDISSSEROTTO, B. Espécies nativas para piscicultura no Brasil. 3.ed. Santa Maria: UFSM, p.147-168, 2020.

GRISDALE-HELLAND, B. et al. The minimum dietary lysine requirement, maintenance requirement and efficiency of lysine utilization for growth of Atlantic salmon smolts. Aquaculture Research, 42(10):1509-529, 2011.

GUIMARÃES, I. G.; MARTINS, G. P. Nutrient requirements of two Amazonian aquacultured fish species, Colossoma macropomum (Cuvier, 1816) and Piaractus brachypomus (Cuvier, 1818): A mini review. Journal of Applied Ichthyology, 31(S4):57-66, 2015.
HAULER, R. C.; CARTER, C. G. Lysine deposition responds linearly to marginal lysine intake in Atlantic salmon (Salmo salar L.) par. Aquaculture Research, 32(1):147-156, 2001.

$H E$, J. Y. et al. Methionine and lysine requirements for maintenance and efficiency of utilization for growth of two sizes of tilapia (Oreochromis niloticus). Aquaculture Nutrition, 19(4):629-640, 2013.

$H E$, J. Y. et al. The effect of dietary methionine concentrations on growth performance of juvenile Nile tilapia (Oreochromis niloticus) fed diets with two different digestible energy levels. Aquaculture Nutrition, 23(4):76-89, 2017.

$H E$, J. Y. et al. Effect of a fish-rice co-culture system on the growth performance and muscle quality of tilapia (Oreochromis niloticus). Aquaculture Reports, 17:100367, 2020.

HELLAND, S. J.; HATLEN, B.; GRISDALE-HELLAND, B. Energy, protein and amino acid requirements for maintenance and efficiency of utilization for growth of Atlantic salmon post-smolts determined using increasing ration levels. Aquaculture, 305(1-4):150-158, 2010.

HUA, K.; SUWENDI, E.; BUREAU, D. P. Effect of body weight on lysine utilization efficiency in Nile tilapia (Oreochromis niloticus). Aquaculture, 505:47-53, 2019.

IQBAL, S. et al. Effect of supplemental selenium in fish feed boosts growth and gut enzyme activity in juvenile tilapia (Oreochromis niloticus). Journal of King Saud University - Science, 32(5):2610-2616, 2020.

KAPS, M.; LAMBERSON, W. R. Biostatistics for Animal Science. Wallingford: CABI Publishing, 2004. 445p.

MATO, J. M. et al. S-Adenosylmethionine synthesis: Molecular mechanisms and clinical implications. Pharmacology \& Therapeutics, 73(3):265-280, 1997.

MICHELATO, M. et al. Dietary lysine requirement to enhance muscle development and fillet yield of finishing Nile tilapia. Aquaculture, 457:124-130, 2016.

NASCIMENTO, T. M. T. et al. Apparent digestibility coefficients for amino acids of feed ingredients in tambaqui (Colossoma macropomum) diets. Revista Brasileira de Zootecnia, 49:e20190032, 2020.

NATIONAL RESEARCH COUNCIL - NRC. Nutrient requirements of fish and shrimp. National. Academy Press, DC, USA, 2011. 376p.

NGUYEN, L. et al. Tryptophan requirement in semi-purified diets of juvenile Nile tilapia Oreochromis niloticus. Aquaculture, 502:258-267, 2019. 
PONZONI, R. W. et al. Genetic paramaters and response for live weigt in the GIFT strain of Nile tilapia (Oreochromis niloticus), Aquaculture, 247(1-4):203-210, 2005.

SAKOMURA, N. K.; ROSTAGNO, H. S. Métodos de pesquisa em nutrição de monogástricos, 2.ed. Jaboticabal: Funep, 2016. 262p.

SILVA, G. F. et al. Programa de melhoramento genético na piscicultura. Embrapa Pesca e Aquicultura-Documentos (INFOTECA- E), 2018. Available in: <http://www.infoteca. cnptia.embrapa.br/infoteca/handle/doc/1093364>. Access in: March, 16, 2020.

SIQUEIRA, J. C. et al. Diet formulation techniques and lysine requirements of 1-to 22-day-old broilers. Brazilian Journal of Poultry Science 15(2):123-134, 2013.

SOUSA, T. J. R. et al. Phosphorus requirements of tambaqui juveniles. Semina: Ciências Agrárias, 39(5):2145-2156, 2018.
SOUZA COSTA, C. M. et al. Efficacy of the essential oils of Mentha piperita, Lippia alba and Zingiber officinale to control the acanthocephalan Neoechinorhynchus buttnerae in Colossoma macropomum. Aquaculture Reports, 18:100414, 2020.

SOUZA, F. O. et al. Methionine plus cystine to lysine ratio in diets for tambaqui juveniles. Revista Caatinga, 32(1):243250, 2019.

STATISTICAL ANALYSIS SYSTEM - SAS. SAS user's guide: Statistics. 5.ed. Cary: SAS Institute, 2002. 956p.

TULLI, F. et al. Response of European sea bass (Dicentrarchus labrax) to graded levels of methionine (total sulfur amino acids) in soya protein-based semi-purified diets. British Journal of Nutrition, 104 5):664-673, 2010.

WOYNÁROVICH, A.; VAN ANROOY, R. Field guide to the culture of tambaqui (Colossoma macropomum, Cuvier, 1816). Rome, Italy: FAO, 2019. 132p. 